\title{
Application of Natural Fibers in Environmental Friendly Products
}

\author{
Darius Gnanaraj Solomon* \\ School of Mechanical Engineering (SMEC), Vellore Institute of Technology, India
}

Submission: August 14, 2020; Published: August 26, 2020

*Corresponding author: Darius Gnanaraj Solomon, School of Mechanical Engineering (SMEC), Vellore Institute of Technology, Vellore, 632014, India

Abstract

Environmental friendly raw materials and products are the need of the hour for manufacturing products which will not pollute the environment during production, during its life time and also after the product serves its useful life. Products dumped in the landfill after retirement should not pollute the environment but should be capable of going through the degradation process without affecting the ecological system. The application of natural fibers is an emerging area in material science which provides solution to this problem. This paper presents various types of fibers from natural resources and their applications in automotive parts, furniture, buildings and construction sectors. Semi-structural parts made of bio-composites are used in automobiles, aero planes, military applications, railway coaches and boats. The paper emphasizes that awareness must be created among product designers to recognize the advantages of bio-composites for extending these composites for designing many more products.

Keywords: Natural fiber composite; Bio-degradable; Environmental friendly; Semi-structural parts, Renewable

Abbreviation: NFRC: Natural Fiber Reinforced Composite; PALF: Pineapple Leave Fiber; LCA: Life Cycle Assessment

\section{Introduction}

Many products or their parts are dumped in landfills and cause environmental degradation. Natural fibers help designers to design products or their parts which are recyclable or biodegradable. Managing waste or generating wealth from waste are very much required for sustaining environment and impact on nature. The most environmentally friendly thing you can do for a car that burns gasoline is to make lighter bodies (Henry Ford). The durability of conventional fiber reinforced plastics is an advantage but glass, carbon, aramid fiber, epoxy and other resins are difficult to dispose. Researchers are finding ways to increase the capacity of plant fibers to replace glass fibers as a 'green' alternative. We need to stop producing parts which do not degrade after serving their useful life. Plastics reinforced with natural fibers provide the best alternative and it may revolutionize the entire World during this century [1]. Inherent environmental benefits are there while using bio-composites. They require less petroleum base oil and the environmental pollution is reduced by using flax/bio-epoxy composites in superlight electric vehicles [2]. Biodegradable plastics and polymers were developed in 1980s. Biodegradable plastics can be made from natural or synthetic polymers. Renewable sources provide the means for producing natural polymers. Biodegradation takes place through chemical degradation or by the action of enzymes from living organisms [3]. Kyoto protocols and $\mathrm{CO}_{2}$ neutral production promote the use of bio-composites. To bring in bio-based economy, raw materials from petroleum resources are to be replaced by natural sources (plants) [4]. This paper presents the current scenario of the biocomposites in many products. Details of different types of natural fibers are presented. Applications of bio-composites in automotive vehicles, aero planes, military vehicles, railway vehicles, building materials, furniture, textiles, construction are highlighted. Awareness is created to motivate product designers to recognize the merits of bio-composites and to use these composites in designing products for many more applications.

\section{Natural Fibers - Types}

Natural fiber plants are shown in Figure 1 and the classification fibers is shown in Figure 2. Different parts of plants give raw materials for producing natural fibers. Parts of different plants give fibers with excellent properties. The trunk portion of soft wood and hardwood are used for making wood fibers. The stem portion of Flax, jute, hemp, kenaf and ramie are used for making fibers with special characteristics. Leaf part of sisal, abaca, pineapple, banana, fique, henequen and palm provide fibers with unique properties. Cotton seed and coconut fruit give fibers for special applications. The grass part of bamboo and rice is useful for producing natural fibers. The following sections give details about each plant. 


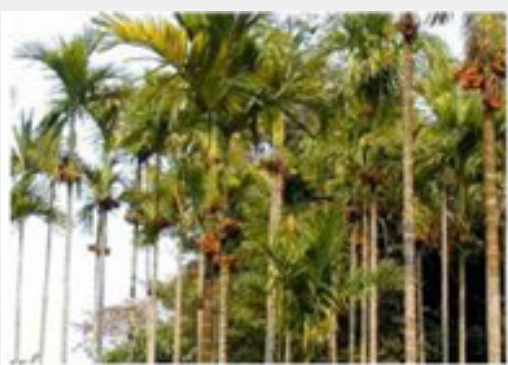

Areca

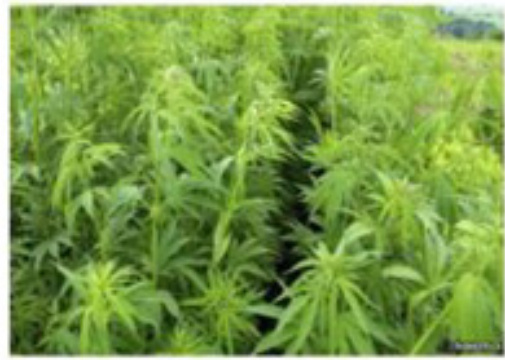

Hemp

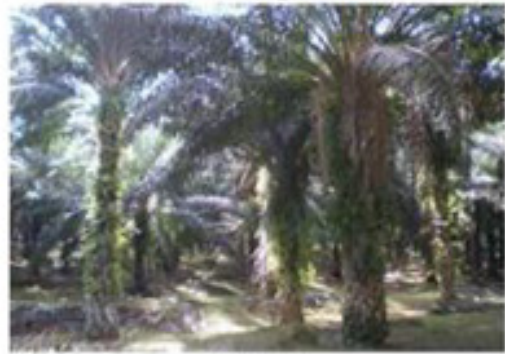

Palm

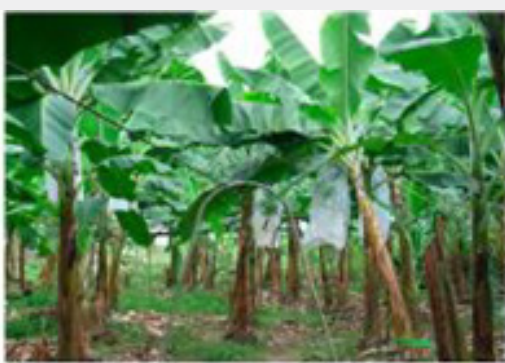

Banana

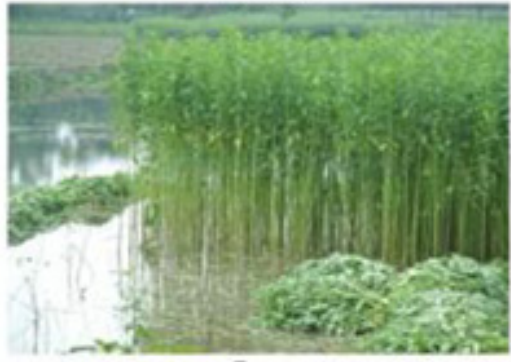

Jute

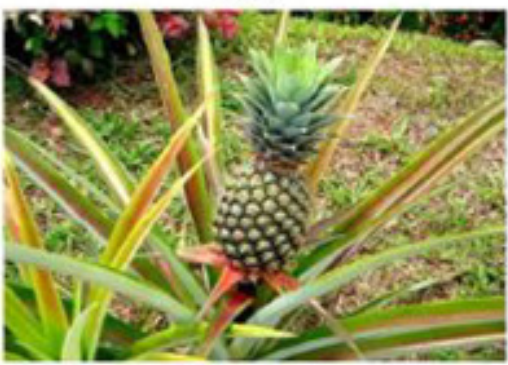

Pineapple

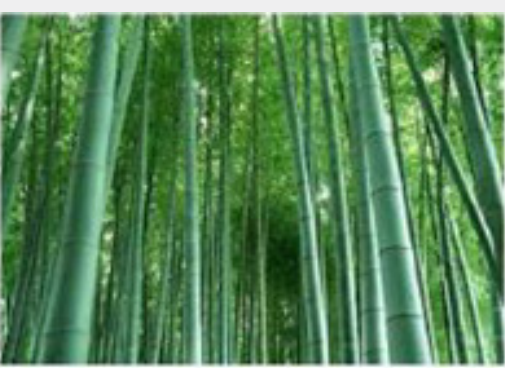

Bamboo

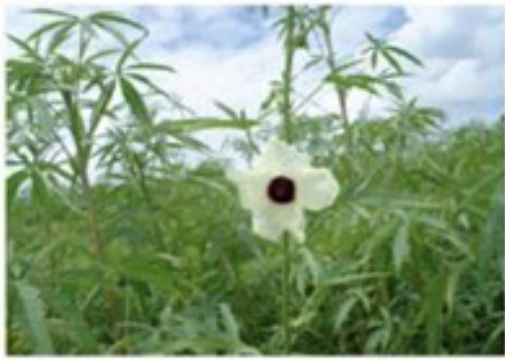

Kenaf

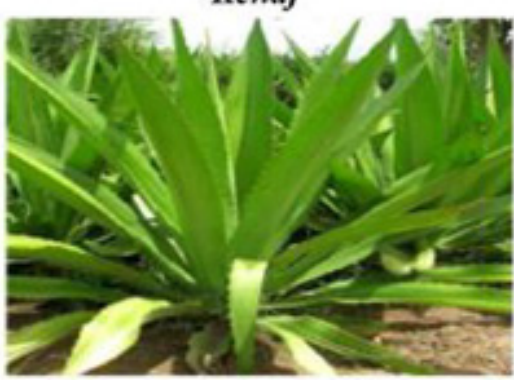

Sisal

Figure 1: Natural fiber plants [15].

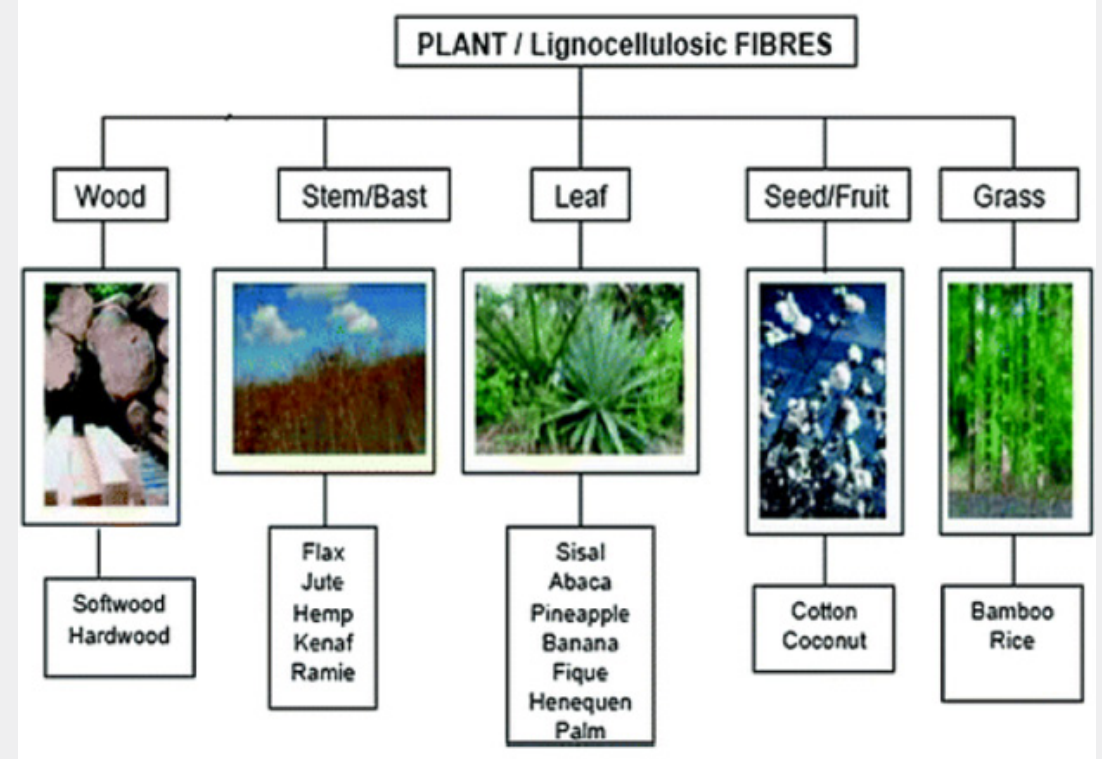

Figure 2: Classification of Natural fibers [20]. 


\section{Wood}

Wood fibers are extracted from hardwood and softwood trees. Fibers can be directly produced or collected from the waste material during the shaping of wood for different application. Used paper products can be used for extracting wood fibers.

\section{Stem/blast}

Flax composites with different lay-up angles and fiber stacking sequences gave a flexural strength of $201 \mathrm{MPa}$ and a tensile strength of $119 \mathrm{MPa}$. Composites having flax yarn gave them a flexural strength of $117 \mathrm{MPa}$ and a tensile strength of $298 \mathrm{MPa}$ [2]. The bark of the jute plant is the source for producing jute fiber. It is known as a golden fiber since it has a silky golden shine. Next to cotton, jute is highly preferred natural fiber in a variety of uses. The normal length of jute is 1 to 4 meters, 17 to 20 microns in diameter and its color is white to brown. It has low thermal conductivity and has insulation property. The threads made form jute fibers are strong [5]. Hemp plant grows to a height of $4 \mathrm{~m}$ and large amounts of carbon are captured by this plant. The outer portion of the plant contains long slender fibers. The diameter of hemp fibers ranges from 16 to 50 microns. Hemp fibers conduct heat and blocks ultraviolet light. Hemp is used in clothing similar to cotton. Long before the birth of Christ, Asians used hemp fibers for making products [6]. Kenaf's tensile strength is 700MPa and its density is 1.2 to $1.4 \mathrm{~g} / \mathrm{cm}^{3}$. The $\mathrm{CO}_{2}$ absorption rate is the highest by kenaf compared to other fibers and it has zero carbon emissions. The energy requirement for producing kenaf fibers compared to glass fibers is about $36 \%$. $40 \%$ of the stalk produces usable fiber which is about twice of the quantity compared to flax, hemp and jute. The plant grows to a height of 3.6 to $4.3 \mathrm{~m}$ in 5 to 6 months. Asian kenaf is utilized for the production of fibers. The plant is available in India, China and Thailand [7]. Ramie strands are $190 \mathrm{~cm}$ long and $25-30$ micron diameter. It is a strong natural fiber, silky and lightweight. It has an extremely high absorbency potential. The strength of ramie fibers increases in wet conditions. It does not shrink and hold its shape. It blends with other fibers easily [8].

\section{Leaf}

Sisal is a hard and coarse fiber having about $1 \mathrm{~m}$ length and a diameter of 200 to 400 microns. It is stretchable, durable, strong and resistant to saltwater. Sisal replaces glass fibers in composite materials. It is extracted from the leaves. Abaca is a fiber available from the leaves. It has good mechanical strength and resistant to damage by saltwater. The fibers are $3 \mathrm{~m}$ long and used for making ropes for rigging ships. It Abaca fibers are used for replacing glass fibers in automobiles [9]. Pineapple leave fiber (PLAF) is abundantly available in the form of waste from food processing industries. It is capable of replacing non-renewable synthetic fibers. PALF is known for its strength and stiffness. Fresh leaves provide about $2.5 \%$ fibers. The arrangement of fibers in PALF is the same as that in cotton [10]. India and other tropical countries cultivate banana plants in a large scale. Banana fibers are mixed with other natural fibers to achieve desired mechanical and thermal properties. Banana fibers have a tensile strength of 600 MPa. Banana fibers are superior to other natural fibers in terms of properties. Cheaper goods in high performing devices are possible with this technology. Application of banana fibers includes sporting goods, ship industry and aerospace industry [11]. Fique fiber has special properties and deserves special attention. Fique plant is native of Columbia and later it spread to neighboring countries. Fique fibers are suitable for polymer composites. The fique fibers have a density of $0.87 \mathrm{~g} / \mathrm{cm}^{3}$ and they are light in weight. They withstand a temperature of about $220^{\circ} \mathrm{C}$. The tensile strength is around $237 \mathrm{MPa}$ and the diameter of fique fibers vary from 0.06 to $0.26 \mathrm{~mm}$ [12]. Henequen fibers are used for making ropes and twines. They are used in shipping and agriculture. Coarse henequen fibers are used for making show soles, bags and fabrics. The plant is closely related to sisal. The plant is grown in Mexico and in surrounding countries. The plant looks like a rosette of sword shaped leave, attached to a thick stem. They yield about 25 leaves annually. Henequen fibers have good strength and it has ability to stretch. It is able to resist deterioration due to saltwater. Henequen market is about to rise since it can replace glass fibers in polymer composites [13]. Palm trees are cultivated in 42 countries including India, Malaysia, Indonesia and West Africa. The advantages of palm fiber include low cost, available in all seasons, biodegradable and environmental friendly, no health hazard and lignin act as a binder. Palm fiber is superior to coconut fiber due to strong bond and the applications include mattress and cushion, erosion control mat, paper production, acoustic absorbers, compost and fertilizer [14].

\section{Seed/fruit}

Cotton has low tensile strength, stiffness but it has high impact strength. Cotton fiber composites are used in safety helmets and interior parts of automobiles which are subjected to impact. Bast and cotton mix offer good tensile stress as well as impact stress and are suitable for many parts of automobiles. Automobile industries are using natural fiber reinforced composite for seat cushions and for interior panels which were made by polymer matrix composites and polymeric foams [15]. Coconut's outer husk is the source for coconut fibers which are used for making mattresses, floor mats and brushes. Coir is available outside the internal shell and inside the outer coat. Coconut fibers are light and strong. It withstands heat and saline water. Crack development in composites is delayed. It is cost-effective, renewable and available in abundance. Coconut coir reduces thermal conductivity. Coconut grows in 90 countries. India contributes $28 \%$ of the world's production. Philippines, Sri Lanka and Indonesia contribute $50 \%$ and the remaining $22 \%$ is contributed by the rest of 86 countries [16]. The areca husk fiber constitutes about $70 \%$ of the weight of the fruit. It originates from Malaysia and east India. South India produces about 6 lakh tons of areca. Low-cost areca fiber reinforced composites find its applications in marine structures, automobile industry, aerospace industry and construction industry [15]. 


\section{Grass}

Bamboo belongs to the grass family. It possesses high mechanical properties, low density and is cheap. It is able to fix atmospheric carbon dioxide. It grows in different climatic conditions and it is abundant in Asia as well as in South America. Baskets, furniture, structural members for temporary sheds are some of the common product made of bamboo bio-composite. Innovative designs using bamboo bio-composites are found in the interior decorations done in Madrid international airport, Spain and in the structure of parking garage, Leipzig zoo, Germany. A lot of innovations in research and development are required for making many more applications of this bio-composite [17]. Biodegradable composite is made using rice husk fiber. This composite has high tensile properties and thermal stability. Rice husk fiber composites are used for making food packaging films and shopping bags. Rice straw bio-composites provide strong plywood materials for household constructions. Plywood made by rice husk has comparable strength with plywood made using teak wood fibers [18].

\section{Natural Fiber Reinforced Composites (NFRC)}

NFRCs are biodegradable, renewable, cheap and recyclable partly. Abaca, areca, banana, bamboo, coconut, cotton, fique, flax, hemp, hardwood, jute, henequen, kenaf, pineapple, palm, sisal, rice, ramie, softwood and many more bio-fibers are used in NFRC. Low density, low cost and environmental friendliness of NFRC helps designers to replace non-renewable fibers by biocomposites $[15,19,20]$. There are many advantages for using NFRC. Some of them are listed below:

a) Low density reducing weight of the product by 10 to b) Good acoustical, thermal and reasonable mechanical properties.

c) Low wear of tools during the production.

d) Environmental friendly throughout the product life cycle.

e) Energy conservation due to savings in weight of parts.

f) Occupational health hazard during recycling is eliminated.

g) Cost of raw materials as well as finished products are less.

Application of Natural Fibers in Developing Environmental Friendly Products

Mechanical properties of bio-composites are lower compared to polymer fiber composites. Surface treatments given to natural fibers will increase the mechanical properties since the interfacial bonding with the matrix material will increase. Many biodegradable polymer materials are developed through research and they replace synthetic resins. These polymers are suitable for use as adhesives, carpet backing and recyclable products. Flax and hemp bio-fibers are used for making products for automobiles, papers, packaging, furniture and building materials. Door panels, dashboards, trays, seat back linings are made of bio-fibers mixed with bio-degradable fibers. Jute based composites are used by Mercedes for E-class door panels, banana fiber composites for A-class and bio-composites for S-Class as shown in Figure 3. Japan produced a fully electric vehicle, "Grass hopper" which is produced using kenaf for the body $[1,21,22]$. $30 \%$.

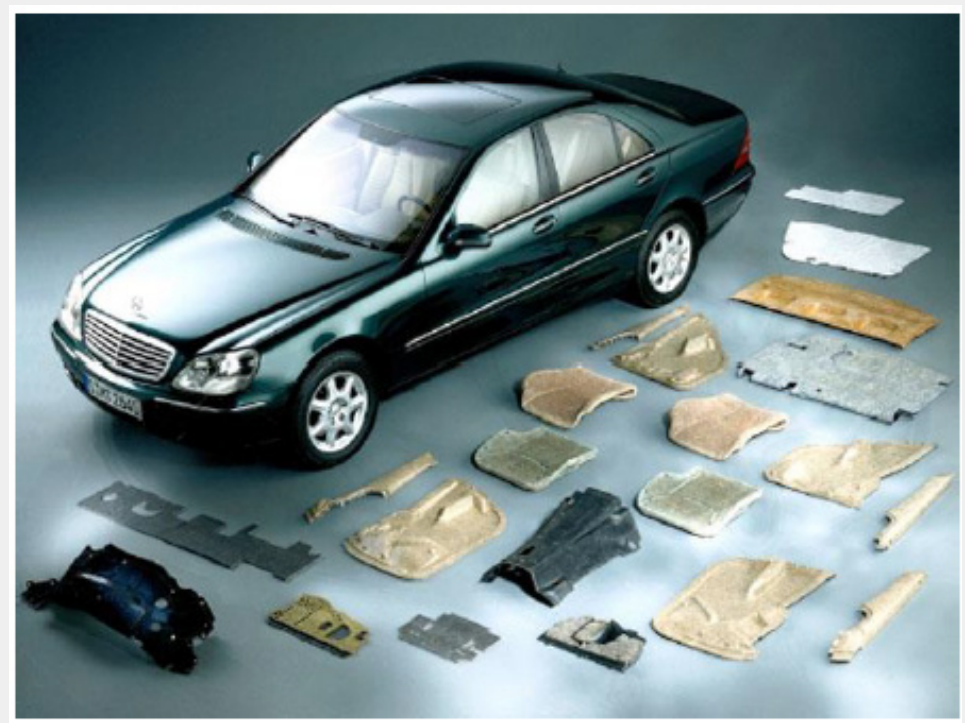

Figure 3: Biocomposites used in an automobile [21]. 
The German aerospace center develops the next generation car (NGC) in collaboration with BASF and BNP Brinkmann. Natural fiber composites using Acrodur binder are used for making part for NGC. Acrodur is a water-based binder without any formaldehyde. It is used for making bio-degradable composites using kenaf, wood, flax and hemp. The weight of parts made of this composite will reduce by $50 \%$ compared to traditional parts made of metal [2]. Toyota used kenaf to strengthen a door trim [3]. The mechanical performance of bio-epoxy/flax composites along with the environmental benefits make them suitable for automobile body chasis, crash elements and body panels [23]. The applications of bio-composites are shown in Table 1 [24]. Figure 4 shows the parking garage of Leipzig zoo in Germany built with bio-composite bamboo.

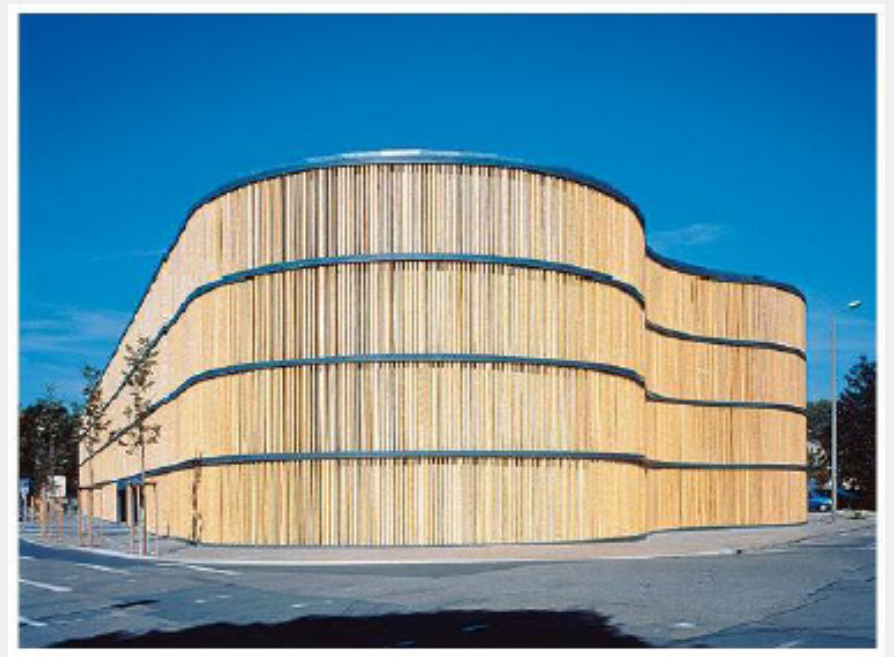

Figure 4: Parking Garage, Leipzig zoo, Germany [17].

Table 1: Applications of bio-composite in industry [24].

\begin{tabular}{|c|c|}
\hline Fiber & Applications \\
\hline Hemp & Paper, textiles, furniture, bank notes, pipes, packaging \\
\hline Oil Palm & Window, door frame, fencing, roof, panel \\
\hline Wood & Deck, window, door, fencing \\
\hline Flax & Tennis racket, bicycle frame, laptop case \\
\hline Rice husk & Bricks, window frame, panels \\
\hline Bagasse & Railing system, panel, deck, fencing \\
\hline Sisal & Paper, pulp, panel, door, roof sheet, shutting plate \\
\hline Stalk & Drains, pipelines, panel, furniture, bricks \\
\hline Kenaf & Mobile case, packing, bag, insulation, clothing, animal bed, oil absorber \\
\hline Cotton & Textile, yarn, goods, furniture, cordage \\
\hline Coir & Flush door shutters, storage tank, helmet, projector cover, post box, seat filling material, broom, brush, yarn, rope, net, bag, mat, \\
padding for mattresses, seat cushion
\end{tabular}

A design competition was conducted to get a design which is attractive, economical and express unity with adjacent zoo grounds. The car park with its bamboo facade gives a different experience to visitors. The garage is wrapped with bamboo sticks placed $7.5 \mathrm{~m}$ apart. Figure 5 shows the Madrid International airport, Spain. $200,000 \mathrm{~m}^{2}$ of ceiling area is covered with bio- composite material, Bamboo. This is the first attempt of this kind in the whole world. The designer has provided a serene and calm environment to travelers through this design. The design offers solace to travelers. It will be good if many architects and civil Engineers come forward to introduce this design in new buildings to promote the use of bio-composite materials [17]. 


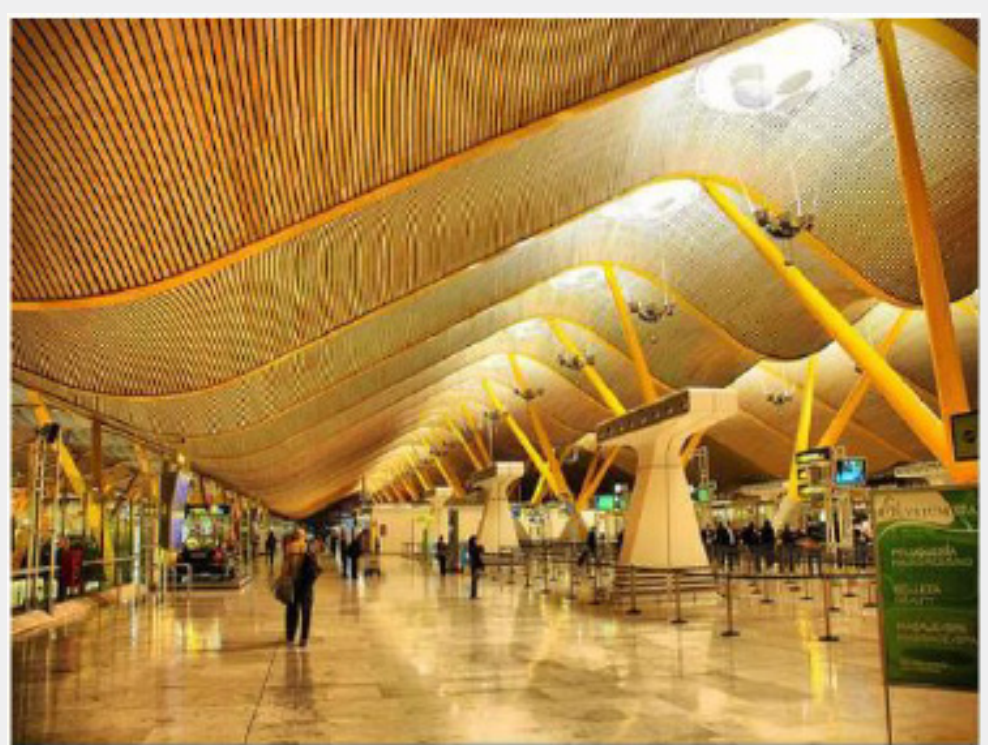

Figure 5: Madrid International Airport, Spain [17].

\section{Future Perspectives}

Natural fibers have many advantages: less pollution, biodegradable, recyclable and environmental friendly. Research needs to be carried out in the following areas:

a) Life cycle assessments (LCA) to assess the reduction in $\mathrm{CO}_{2}$ release.

b) Promotion of growth of plants which supply bio-fibers as well as consume more $\mathrm{CO}_{2}$ to make the atmosphere environment friendly

c) Natural fiber reinforced composite (NFRC) is an emerging area in material science. An awareness has to be made to product designers for designing with NFRC for reducing the environmental pollution

d) Many more designs in-line with Madrid Airport, Spain and Leipzig zoo, Germany are to be introduced in many parts of the world to promote the use of bio-composites [22-25].

\section{Summary}

The pollution, health problems, cost and energy requirements of glass fiber are motivating its replacement by bio-fibers. Natural fibers are sourced from different parts of plants. Fibers with excellent properties are taken from wood, stem/bast, leaf, seed/fruit and grass of different plants. Many products made of natural fibers are presented. Natural fiber reinforced composites are cheap, renewable, biodegradable and partly recyclable. Biocomposites make use of fibers taken from abaca, areca, banana, bamboo, coconut, cotton, fique, hemp, flax, hardwood, jute, henequen, palm pineapple, kenaf, sisal, rice, ramie, softwood and many more natural fibers. This paper highlights applications of bio-composites in automobiles, aero planes, military vehicles, railway vehicles, building materials, furniture, textiles and construction. The use of bio-composites in Mercedes interior parts, Madrid airport interior design and Leipzig zoo Germany are highlighted. Product designers are motivated to utilize biocomposites in their new designs to march towards a pollution free environment.

\section{References}

1. Ramli N, Mazlan N, Ando Y, Leman Z, Abdan K, et al. (2018) Natural fiber for green technology in automotive industry: A brief review. IOP Conference Series: Materials Science and Engineering 368: 012012.

2. Zhu J, Immonen K, Avril C, Brighton J, Zhu H, et al. (2015). Novel Hybrid Flax Reinforced Supersap Composites in Automotive Applications. Fibers 3(1): 76-89.

3. Abilash N, Sivapragash M (2013) Environmental benefits of ecofriendly natural fiber reinforced polymeric composite materials. International journal of application or innovation in engineering and mangagement (IJAIEM) 2(1): 53-59.

4. Jan EG van Dam, Wageningen University, The Netherlands.

5. Jabbar A (2017) Literature Review. In: Sustainable Jute-Based Composite Materials. Springer Briefs in Applied Sciences and Technology. Springer.

6. Mahapatra NN (2018) Extraction, processing, properties and use of hemp fiber.

7. John Pellettieri (2019) Kenaf - Natural fiber for lightweighting. Material Matters.

8. Advantages and disadvantages of Ramie fibers (2015).

9. Profiles of 15 of the world's major plant and animal fibers (2019).

10. Asim M, Abdan K, Jawaid M, Nasir M, Dashtizadeh Z, et al. (2015) A Review on Pineapple Leaves Fiber and Its Composites. International Journal of Polymer Science, pp. 1-16. 
11. Bhatnagar R, Gupta G, Yadav S (2015) A Review on Composition and Properties of Banana Fibers. International Journal of Scientific \& Engineering Research 6(5): 49-52.

12. Teles MCA, Altoé GR, Amoy Netto P, Colorado H, Margem FM, et al. (2015) Fique Fiber Tensile Elastic Modulus Dependence with Diameter Using the Weibull Statistical Analysis. Materials Research 18(suppl 2): 193-199.

13. Henequen Market Forecast, Trend Analysis \& Competition Tracking Global Review 2018 to 2028 - A report.

14. Sanjay MR, Arpitha GR, Nail LL, Gopalakrishna K, Yogesha B (2016) Applications of natural fibers and its composites: an overview. Natural resources 7: 108-114.

15. Palm fiber: Heng Huat group.

16. Verma D, Gope P (2014) The use of coir/coconut fibers in composites. In book: biofiber reinforcement in composite materials. In: Faruk O, Sen M (Eds.), University of Toronto, Canada. Wood head publishing house.

17. Kaur N, Saxena S, Gaur H, Goyal PA (2017) Review on Bamboo Fiber Composites and its Applications. International Conference on Infocom Technologies and Unmanned Systems (ICTUS'2017), Dec. 18-20, 2017, ADET, Amity University Dubai, UAE, 978-1-5386-0514-1/17/\$C2017 IEEE.
18. Singh SK, Murthy JN, Varma P, Sailaja D (2014) Study of Rice Straw Biocomposite and a Comparative Study of Flexural Strength of Various Biocomposite Plywood Materials. Int'l Journal of Advances in Agricultural \& Environmental Engg (IJAAEE) 1: 19-22.

19. Chandramohan D, Marimuthu K (2011) A review on natural fibers International Journal of Recent Research and Applied Studies (IJRRAS) 8(2): 195-206.

20. Thyavihalli Girijappa YG, Mavinkere Rangappa S, Parameswaranpillai J, Siengchin S (2019) Natural Fibers as Sustainable and Renewable Resource for Development of Eco-Friendly Composites: A Comprehensive Review. Frontiers in Materials 6: 1-14.

21. Automotive composites (2011).

22. Light-weight natural-fiber composite deployed in German Next Generation Car project, Plastics today.

23. Peças P, Carvalho H, Salman, H, Leite M (2018) Natural Fibre Composites and Their Applications: A Review. Journal of Composites Science 2(4): 66.

24. Mohammed L, Ansari MNM, Pua G, Jawaid M, Islam MS (2015) A Review on Natural Fiber Reinforced Polymer Composite and Its Applications. International Journal of Polymer Science, pp. 1-15.

\begin{tabular}{|l|}
\hline \multicolumn{1}{|c|}{ Your next submission with Juniper Publishers } \\
will reach you the below assets \\
- Quality Editorial service \\
- Swift Peer Review \\
- Reprints availability \\
- E-prints Service \\
- Manuscript Podcast for convenient understanding \\
- Global attainment for your research \\
- Manuscript accessibility in different formats \\
( Pdf, E-pub, Full Text, Audio) \\
- Unceasing customer service \\
Track the below URL for one-step submission \\
https://juniperpublishers.com/online-submission.php \\
\hline
\end{tabular}

